\title{
Politeness Principles Violation of "Mind Your Language" Comedy Series: A Pragmatic Analysis
}

\author{
Eko Purwanti ${ }^{1 *}$, Hilmy Herbianto ${ }^{2}$ \\ ${ }^{1,2}$ English Language Education Department, Faculty of Language Education, Universitas Muhammadiyah Yogyakarta, \\ Indonesia, 55183 \\ *Corresponding author. Email: ekopurwanti@umy.ac.id
}

\begin{abstract}
Communication happens when two people or more interact verbally. To make communication run smoothly, people must pay attention to communication principles, namely cooperation and politeness principles. However, sometimes these communication principles are intentionally violated, especially for creating humor purposes. This study aimed to analyze the types of politeness principles violation found in Mind Your Language comedy series, and the effect of these politeness principles violation towards the characters in Mind Your Language comedy series. This study used a qualitative approach, using descriptive qualitative research design. The instrument of the study was the video of Mind Your Language comedy series. In addition, in collecting the data, the scripts and the video of Mind Your Language comedy series from episodes 1-5 were used. The findings show there were six types of politeness principles violation consisting of six maxims: tact maxim, generosity maxim, approbation maxim, modesty maxim, agreement maxim, and sympathy maxim. In addition, the politeness principles violation in Mind Your Language comedy series has fourteen effects, namely curious, confused, trusted, angry, annoyed, shy, shocked, panic, happy, bored, enthusiastic, laugh, disappointed, and strange. These findings imply that languages used in a certain context may have different meaning, and therefore students of English Language Education should be aware about such situation. Therefore, teaching foreign languages should also include not only semantics but also pragmatics.
\end{abstract}

Keywords: Maxim violation, generosity maxim, approbation maxim, modesty maxim, agreement maxim, tact maxim, and sympathy maxim

\section{INTRODUCTION}

Humor has an important aspect in human being. Understanding humor in the current situation can be used to release tiresome, fatigue and stress. Matwick [1] mentioned that humor is a tool for managing social control and displaying self-identity. Furthermore, Dynel [2] divided humor into two criteria; the first one is stylistic figures (e.g., metaphor, irony, paradox, punning or figurative) and the second one is pragmatic figures (e.g., jokes, humor or humiliation). Koestler in Ma and Jiang [3] gave general classification of humor which are verbal humor and situational humor.

The linguistic research on humor is done both semantically and pragmatically. Humor from the perspective of pragmatics is posed by someone that can have a hidden meaning or intention so that it is interesting to analyze the relationship of humor in conversation. In addition, humor occurs when the listener cannot catch the message or may not fully understand the utterance from the speaker that cause conflict during communication.

Lynch [4] stated that humor has no boundaries, and people may have different taste of humor. That is why sometimes people have different interpretations of humor. The form of humor can be seen not only in real life communication but also on television, radio and printed media such as book, novel, or comic. Almost every day in our life, viewers are provided with jokes/humor/comedy programs on television. In linguistic contexts, humor is created by violating the politeness principle $[5,6]$. When the message is not delivered in an appropriate way, it makes the listener feel humiliated or offended by the speaker; however, it sometimes turns out to create a humor [7]

Communication is one of the main aspects of human needs. Through language, humans convey what they feel, and what they want to talk about with the others. In every communication, there are always two aspects; the speaker and the listener. In every conversation between them, the listener should be able to interpret the meaning from the speaker's utterances. Sometimes when people have a conversation, the speaker has another meaning behind what is said, and that is why the listener should interpret to understand the message. Greenfield as stated in [8] defined that meaning in communication is called pragmatics. Greenfield said that meaning is not only something in the word itself, nor something from the speaker utterances, nor something to the listener interpretation, but also a bound of three of them. Besides, according to Leech as stated in [8] pragmatics is a study of how language is used in a particular situation. In line with Leech, Levinson defines pragmatics as a branch of linguistics that studies the relation of language and the context [8].

When people communicate, the speaker and the listener must obey politeness principles, and failing to do so will 
result in uncomfortable situation. [9] defined three basic conditions of politeness; 1) do not impose on others; give others the right of choice; 2 ) be friendly with each other, and 3) make each other feel good. In addition, [8] said that politeness is an interpersonal relationship designed to facilitate the interaction or communication. Finally, Leech defines politeness as a human behavior that is expressed in a good way [8].

There are six maxims of politeness principles, those are; tact maxim, generosity maxim, approbation maxim, modesty maxim, agreement maxim, and sympathy maxim. These maxims are considered as the extension of Lakoff's three conditions of politeness. Those six maxims are intended to make the speakers and the listeners, or the communicators feel comfortable. Brown and Levinson said that in communicative activities, both sides have to respect each other and consider the feelings [9]. In conclusion, politeness principle is maintaining a proper speaking to the others without offending them.

However, in a certain condition, these politeness principles are violated to create humor. How the politeness principles are violated, and what effects are caused by these principles are interesting to observe. There are at least three factors which make humorous utterances in Mind Your Language comedy series, namely mispronunciation, lexical ambiguity and politeness principles violation.

Based on the above issues, the researchers are interested in analyzing the politeness principle violation of Mind Your Language comedy series. Mind Your Language comedy series is a British comedy series that was premiered on ITV in 1977. The series shows how people from different countries and language learn English together. The focus of this show is a teaching-learning process of English as foreign language students in a college in London. The communication in classroom does not work well because the students have lack of English' speaking ability and students have different mother tongue language. Therefore, the teacher and the students often misunderstood each other. In order to focus on the topic, this study aimed to seek two things; 1) the type of politeness principles violation in the comedy series of Mind Your Language, and 2) the purposes of the violation made by the speaker in the comedy series of Mind Your Language.

\section{LITERATURE REVIEW}

Communication is necessary in human being. People always have conversation with each other every day. People communicate through language as the media of communication. By using language people can deliver information and maintain relationship with the other. Communication happens when there are two people interacting using a language which is called speaker and listener. Communication is going well when both of them can understand the meaning each other. Every speaker should have responsibility to every utterance that occur in communication, whether the use of good and correct vocabulary and pay attention to language politeness since it is important thing in communication. According to [10], there are communication principles that should be considered and followed by the communicator to develop a smoothly interaction. Those communication principles are cooperative principle and politeness principle.

One of the first scholars who concentrated on linguistic politeness in a pragmatic aspect was Lakoff, who defined politeness as an interpersonal relationship designed to facilitate the interaction with the others [8]. Lakoff as cited in [11] stated that "the pillars of our linguistic as well as nonlinguistic interactions with each other are to make one clear and be polite". Concerning the second pillar, 'be polite', Lakoff proposes three rules of politeness: formality, meaning "don't impose, give others the right choice"; "be friendly with each other" or "make each other feel good" [9].

Furthermore, politeness is the symbol of human civilization and an important criterion of human social activities. Generally, Leech as stated in [8] defines politeness principle as "just use as little as possible utterances that consist of impolite expressions". Leech presents the politeness concept by using terms such; self and other. 'Self' refers to speaker, and 'other' refers to the opponent or the interlocutor. An utterance is considered polite if the speaker uses polite words, does not rule directly, and respect the others. In addition, Leech put a simple definition of politeness as a behavior that is expressed in a good or ethical way. That is the ability to engage in social interaction in harmony atmosphere [12]. Politeness principle is seen as an attempt to avoid conflicts between speaker and listener. Politeness principle is a key to use language, and in language it is necessary to consider the feelings of others. In short, Lulu [13] summed up politeness principle as "minimize the benefits of others, to maximize the benefits of others; to maximize damage of others and to minimize the damage of others." It can be concluded that language politeness is very important in speaking. Because by paying attention to the language politeness, people enable to create a harmony relationship between speakers and listener in communication [4].

Leech as stated in Miranda [14] proposes that politeness principles are based on three pragmatic scales which are; costbenefit, indirectness and optionally. The most important of the three is the cost-benefit scale which captures the social agreement based on which people have to do their best to act in ways that are beneficial for the others. The higher the cost to the listener, the less polite the utterances; and the lower the cost (or the higher the benefit) the more polite it is. The indirectness scale has to do with the degree of indirectness of an act. The more indirect utterance is, the more polite, however it is regarding on the purpose of the conversation. That is why the concept of optionality is needed. The optionality scale accounts for the choice given to the listener to refuse or to say no (negative politeness). The three scales are interrelated, the higher the cost the more indirect the utterance will be and the greater the amount of optionality to 
the interlocutor. These scales underlie all six maxims of politeness principle, namely tact maxim, generosity maxim, approbation maxim, modesty maxim, agreement maxim, and sympathy.

\subsection{Politeness principles}

Politeness principles consist of six maxims comprising tact, generosity, approbation, modesty, agreement, and sympathy. The following explains these maxims in more details.

\subsubsection{Tact Maxim}

Tact can be defined as a skill of understanding shown by someone who handles people and situations without causing offence. Leech divides tact maxim into two: "Minimize cost to others" and "Maximize benefit to others" [14]. The basic idea of tact maxim is that the communicator should always be aware to the principle of reducing their own benefit and maximizing the other's benefit in communication. In this case, Leech said that the longer a person's speech the greater the person's desire to be polite to the others. In addition, indirect speech is usually more polite than direct speech [8].

"Minimize cost to others" means the higher the cost the more indirect the utterance will be [14] For the example: the expression "Open the door!" is direct instruction and it is less polite compares to "Could you please open the door?" or "Would you mind open the door?" are considered more polite because it increases indirectness and the degree of optionality. Thus, the cost is minimized, and it is considered as polite. On the other hand, "Maximize benefits to others" means the higher the benefit the less indirect the utterance will be. In example, for an offer directness is expected rather than indirectness. Expression such as "Please have some more cake!" is maximize the benefit for the addressee.

Another example of tact maxim can be seen in teaching and learning activity such as; "Could you have a try to answer the question? I will help you." If teacher ask students more politely, it will eliminate student's tension and increase their willingness to participate in classroom activity [15].

\subsubsection{Generosity Maxim}

Leech as stated in [12] defines generosity maxim is when speakers maximize respect for others and minimize disrespect to others. The purpose of generosity maxim is to make speaker's profit as little as possible and make speaker's loss as big as possible [8]. Generosity maxim correlates with Tact maxim that is "self-centered". Leech as stated in [14] said that generosity maxim and tact maxim can work together. As an example, in the utterance "You may borrow my book," there is a disadvantage for the speaker and the benefit for the addressee. A higher level of politeness can be achieved if the listener is not mentioned as the benefactor, for example: "Can I have a tea?" and even more polite if the speaker does not appear as the beneficiary, as an example: "Is there any tea?"
In addition, Liu[15] said that apologetic words usually used by teacher to express their generosity to students.

\subsubsection{Approbation Maxim}

Leech as stated in [12] said that approbation maxim requires each communicator to maximize the loss for himself, and minimize his own advantage. In addition, approbation maxim is an attempt to avoid saying unpleasant things about the listener [8]. For the example, as adapted from Liu[15] students have desire to be appreciated by teachers. Teachers should use approbation maxim to appreciate and encourage student's achievements. Here is the example: "Well done! You did a great job in the last exam." By saying this word, it will increase student's confidence and participation in classroom activity.

Approbation maxim is not only can be used to appreciate when students did a good job, but when students give a wrong answer, teachers should also use this maxim to not offended student's feeling like "You have made much progress, but I think you can do it better if you study harder" Students will accept the word pleasantly, because the teacher fully respects them.

\subsubsection{Modesty Maxim}

Leech as stated in [12] defines modesty maxim is "selfcentered." This maxim requires every communicator to minimize self-respect. In modesty maxim, the communicators are expected to be humble by reducing the praise of themselves. As the example:

\section{A: "You are a great singer! You sing very well" \\ B: "Sure, I have a golden voice!"}

Person B is considered impolite because he maximizes praise on himself. On the other hand, if he replies, "Thank you, but I think I am not that good," it is considered more polite, and it is the answer that is more expected by the listener than the first one.

\subsubsection{Agreement Maxim}

Leech as stated in [12] defines agreement maxim is purposed to maximize compatibility and incompatibility between speaker and listener. Agreement maxim emphasized that all communicators speak to one another mutually appropriates or the compatibility is created among them in the communication. As the example:

A: "Do you feel hot in this room?"

$B$ : "Where is the AC remote control?"

From the example above, there is the same perception between person $\mathrm{A}$ and $\mathrm{B}$ that they are feeling hot in the room. Person B agrees with person A, so he asked: "Where is the AC remote control?" 


\subsubsection{Sympathy Maxim}

Leech as stated in [12] defines sympathy maxim is expressed by assertive and expressive utterances. This maxim requires every communicator to maximize sympathy and minimize antipathy to the listener. If the listener speaks about happiness, the speakers have to give congratulation. When the listener said to get distress, or misfortune speakers deserve grief, or expressed condolences as a sign of humbleness. The following is the example:

A: "Finally the company is hire me!"

B: "Wow, congratulation on your new job, Good luck!"

In the example above, person A express about his success and happiness then person $\mathrm{B}$ give him congratulation. The six maxims of politeness principle are influenced by the distinction between negative and positive politeness. Negative politeness consist of minimizing impoliteness while positive politeness involves maximizing politeness. Leech said that speech acts in politeness principle can be either "other-centered" or "self-centered", and thus bilateral, which is seen in the tact and generosity maxim as well as in the approbation and modesty maxim [14]

Based on these six maxims, not all of maxims are equally important. [12] stated that tact maxim influences what we say more powerfully than generosity maxim, while approbation maxim is more important than modesty maxim. They added that speaker may use more than one maxim at the same time. In addition, Leech as stated in [14] said that "Tact maxim is the most important kind of politeness in English-speaking society."

\section{METHODOLOGY}

This study used a qualitative approach. Creswell [16] said that qualitative research is best to address the research problems in which we did know the variables and need to explore. The subject of this study were Mind Your Language comedy series, and the research object were politeness principles violation used by the characters in Mind Your Language comedy series. This study used the politeness principles theory by Leech (1983) which consisted of six maxims, comprising tact maxim, generosity maxim, approbation maxim, modesty maxim, agreement maxim, and sympathy maxim [17].

The instrument of this research was Mind Your Language comedy series. The researchers watched and transcribed the conversation in Mind Your Language comedy series episode $1,2,3,4$ and 5 which contained violation of politeness principle in the characters' utterances. These transcriptions were used as the data and analyzed by the researchers to answer the research questions. There were two reasons why the movie was chosen as the source of the data; first Mind Your Language comedy series represents daily life conversation which tells about teaching and learning situation with different social background and languages, and it is still related to nowadays situation. Second, the genre of Mind Your Language comedy series was education which was related with the researchers' subject.

The data of this study was collected by using documentation technique with the following procedures; first, the researchers watched Mind Your Language comedy series as the source of data while transcribing the conversations. Mind Your Language Comedy Series was a British comedy series that premiered on ITV in 1977. The series shows how people from different countries and language learn English together. The focus of this show was a teaching-learning process of English as foreign language students in a college in London. This comedy series had three seasons consisting of 42 episodes with more or less 25 minutes length for each episode and the researchers used only five episodes to analyze. Afterwards, the researchers classified the utterances that considered as politeness principles violation. Finally, the researchers gave codes in each data.

\section{FINDINGS AND DISCUSSIONS}

The study aimed to find out the violations of politeness principles in Mind Your Language comedy series [1]. In conducting the research, two research questions were formulated, namely 1) What are the politeness principles violation in Mind Your Language comedy series? 2) What are the effects of politeness principles violation in the conversation? To answer these research questions, the researchers analyzed the comedy series from episode one to five. In order to analyze the politeness principles violation maxims, the theories of Speech Act from Leech (1983) was used, comprising tact maxim, generosity maxim, approbation maxim, modesty maxim, agreement maxim, and sympathy maxim.

Based on the data analyses, the findings show several things, namely 1) regarding the first research question, there are six politeness principles maxims that are violated in the Mind Your Language comedy series, namely tact maxim, generosity maxim, approbation maxim, modesty maxim, agreement maxim, and sympathy maxim, 2) there are fourteen effects caused by the maxim violations, comprising curious, confused, trusted, angry, annoyed, shy, shocked, panic, happy, bored, enthusiastic, laugh, disappointed, and strange.

In order to give clear explanation about the findings, there are two ways of presenting the finding. The first, the summary of the findings including the types of the maxim violations, and the effect of the maxim violations. Second, the detail explanation about the types, the effect, and the purposes is presented in one complete context, meaning that the researchers mentions the types of maxim violation, and then followed by the effects of the maxim violation all in all. As there are quite many data regarding these two features, the researchers take only few and presents them in a complete context.

Based on the data, there are 42 utterances in episode 1-5 that are considered as politeness principles violation. In a 
more detail explanation, there are 20 utterances that are considered as violation of tact maxim. Next, there are 13 utterances considered as violation of approbation maxim. The violation happened because the speaker maximized dispraise to others by saying some utterances. There are 3 utterances considered as violation of modesty maxim. Then, the researchers found 4 utterances that are considered as violation of agreement maxim. Finally, there was only one utterance that is considered as sympathy maxim. As mentioned earlier, detail explanation about these findings were analyzed based on what situation was when the conversation happened and its form of violation of politeness principles, as well as the effect and the purpose.

The researchers found some effects due to politeness principles violation in the conversation between the speaker and the interlocutor. There are fourteen types of effects taken from 42 utterance. All the effects found in Mind Your Language comedy series happened purposely to create the humorous situations. The following section describes the types of politeness principles violation which were found in the Mind Your Language comedy series, and then followed by the effects of these politeness principles violations.

\subsection{Types of Politeness Principles Violations}

\subsubsection{Violation of Tact Maxim}

Tact Maxim can be defined as a skill of understanding shown by someone who handles people and situations without causing offence. Leech divides tact maxim into two: "Minimize cost to others" and "Maximize benefit to others"[14] The basic idea of tact maxim is that the communicator should always aware to the principles of reducing their benefit and maximizing the other's benefit in communication. However, in Mind Your Language comedy series, the actors ignored tact maxim in order to create humorous utterances. The violation of tact maxim happened because the actors of Mind Your Language comedy series maximize cost to others and minimize benefit to others. The followings are the violation of tact maxim in Mind Your Language comedy series.

\section{Scene 1.}

Miss Courtney : By the way, how's the femme fatale?

Mr. Brown :-Ah Yes Danielle (student), at the moment, she is in the tearoom with Italy, Spain and Greece trying to establish diplomatic relations. (Episode 1/14.53')

\section{Situation:}

This conversation happened in Miss Courtney's room on break time. It involves Miss Courtney and Mr. Brown. They are discussing about students. Suddenly Miss Courtney asks the students called Daniela to Mr. Brown and Mr. Brown directly answer that Daniela is in the tearoom with Italy (Mr. Max), Spain (Mr. Giovanni), and Greece (Miss. Sue) to establish diplomatic relations.

\section{Data Interpretation:}

Miss Courtney asks to Mr. Brown about Daniela and Mr. Brown reverses the fact that Daniela is actually not establishing diplomatic relation, but she just gathers with her friends from different country in the class. There is a violation of tact maxim in this conversation because Mr. Brown has reversed the fact. In fact, diplomatic relations just happen in a formal meeting to discuss cooperation among countries, but Daniela is just student who study in England.

\section{Scene 2.}

Mr. Brown $\quad:$ Did you fly?
Mr. Kenyon $\quad:$ Fly? What did you mean bwana?
Mr. Brown $\quad$ : Fly, in a big iron bird, quite a change from
riding on elephant, unless you came by Jumbo. (Mr. Brown
laughing) English joke. (Episode 2/17.34')
Situation:

This conversation happened in a class. It involves $\mathrm{Mr}$. Kenyon and Mr. Brown. Mr. Kenyon actually is the school inspector, but Mr. Brown does not know him. Mr. Brown assumes that Mr. Kenyon is new students who came from Africa. When Mr. Kenyon joins the class, Mr. Brown directly asks him with a strange question that confuses Mr. Kenyon.

\section{Data Interpretation:}

Mr. Brown confused the interlocutor with his utterance. "Fly, in a big iron bird, quite a change from riding on elephant, unless you came by Jumbo. (Mr. Brown laughing) English joke." This utterance is actually a parable, but Mr. Kenyon does not understand the meaning. That is why violation of tact maxim happened in the conversation.

\subsubsection{Violation of Generosity Maxim}

Leech as stated in [12] defines generosity maxim is when speakers maximize respect for others and minimize disrespect to others. The purpose of generosity maxim is to make your profit as little as possible and make your loss as big as possible [8]. However, in Mind Your Language comedy series the actors ignored generosity maxim in order to create humorous utterances. The violation of generosity maxim happened because the actors of Mind Your Language comedy series minimize respect for others and maximize disrespect to others. The following is the violation of generosity maxim in Mind Your Language comedy series.

\section{Scene 1.}

Mr. Kenyon: His teaching methods may be revolutionary, but they appear to work.

Miss. Courtney: I've always encouraged my stuff to be forward thinking. (Episode 2/21.57') 


\section{Situation:}

This conversation happened in the class. It involves Mr. Kenyon, Mr. Brown and Miss Courtney. Miss Courtney enters Mr. Brown's class and talks to Mr. Brown that Mr. Kenyon is an inspector school. Mr. Brown is shocked. Mr. Kenyon praises his teaching methods. Suddenly Miss Courtney says "I have always encouraged my stuff (Mr. Brown) to be forward thinking".

\section{Data Interpretation:}

Miss. Courtney clarifies to Mr. Brown that Mr. Kenyon is not a student, but he is an inspector school. Mr. Brown apologizes to Mr. Kenyon because of the accident but Mr. Kenyon feels happy because the teaching method in Mr. Brown's class is very good. Suddenly Miss Courtney says "I have always encouraged my stuff (Mr. Brown) to be forward thinking. There is a violation generosity maxim in this conversation because Miss. Courtney maximizes benefit to self and utilizes ignorance of the interlocutor that Miss Courtney has always encouraged her stuff to be forward thinking.

\subsubsection{Violation of Approbation Maxim}

Leech as stated in [12] said that approbation maxim requires each communicator to maximize the loss for himself, and minimize his own advantage. In addition, approbation maxim is an attempt to avoid saying unpleasant things about the listener [8]. Otherwise, in Mind Your Language comedy series the actors ignored approbation maxim in order to create humorous utterances. The violation of approbation maxim happened because the actors of Mind Your Language comedy series maximize dispraise and maximize advantage. The following are the violation of approbation maxim in Mind Your Language comedy series.

\section{Scene 1.}

Miss. Rita: It is his duty to be marrying me otherwise I am losing my face.

Mr. Max: I think she's is lost it already. (Episode 3/20.53')

\section{Situation:}

This conversation happened in front of the class. It involves Miss Rita, Mr. Max and Mr. Juan. Miss Rita and Mr. Ranjeet were both betrothed when they were children. Now, Mr. Ranjeet does not want to marry her. Miss Rita is disappointed because she is losing her face. Suddenly Mr. Max and Mr. Juan talk to her that she is lost it already.

\section{Data Interpretation:}

Miss Rita feels disappointed because Mr. Ranjeet does not like her again. Miss Rita is losing her face. Suddenly Mr. Max and Mr. Juan say that Miss Rita is lost it already and she feels offended. There is a violation of approbation maxim in this conversation because Mr. Max and Mr. Juan maximize dispraise to others and offended the interlocutor.

\subsubsection{Violation of Modesty Maxim}

Leech as stated in [12] defines modesty maxim is "selfcentered." This maxim requires every communicator to minimize self-respect. In modesty maxim, the communicator is expected to be humble by reducing the praise themselves. However, in Mind Your Language comedy series the actors ignored modesty maxim in order to create humorous utterances. The violation of modesty maxim happened because the actors of Mind Your Language comedy series maximize praise of self. The following is the violation of generosity maxim in Mind Your Language comedy series.

\section{Scene 1.}

Mr. Brown : Perhaps you would like to sit next to Ali, your countryman.

Mr. Ranjeet $\quad$ : I cannot sit there. It is impossible.

Mr. Brown : Why is it impossible?

Mr. Ranjeet $\quad$ : I am Sikh. (Episode 1/11.00')

Situation:

This conversation happened in a class. It involves Mr. Brown and Mr. Ranjeet. They are from the same country in India. When Mr. Ranjeet comes late to the class, he does not want to sit down near Mr. Ali because both of them are different tribe. Mr. Ranjeet is Sikh while Ali is Barbarian.

\section{Data Interpretation:}

Mr. Ranjeet and Ali is one countryman. Both of them have a different belief and doctrine. Mr. Ranjeet is Sikh while Mr. Ali is Barbarian. Sikh is more religious than Barbarian. There is violation of modesty maxim in this conversation because Mr. Ranjeet maximizes praise of self. He always assumes Barbarian is poor and Sikh is the superior.

\subsubsection{Violation of Agreement Maxim}

Leech as stated in [12] defines agreement maxim is purposed to maximize compatibility and incompatibility between speaker and listener. Agreement maxim emphasized that all communicators speak to one another mutually appropriates or the compatibility is created among them in the communication. However, in Mind Your Language comedy series the actors ignored agreement maxim in order to create humorous utterances. The violation of agreement maxim happened because the actors of Mind Your Language comedy series minimize compatibility and incompatibility. The following is the violation of agreement maxim in Mind Your Language comedy series. 


\section{Scene 1.}

Mr. Brown : Yes, we'll imagine this table is the bank counter and I am the bank. You are a costumer and you're coming to cash a check, all right?

$\begin{array}{ll}\text { Mr. Taro } & : \text { Ok. } \\ \text { Mr. Brown } & : \text { Good morning sir. }\end{array}$

Mr. Taro: It is not good morning time, it is good night time. (Episode 5/9.06')

\section{Situation:}

This conversation happened in a class. It involves Mr. Brown and Mr. Taro. Mr. Brown demands to all students practice a conversation. Mr. Brown asks to Mr. Taro to Imagine that Mr. Brown is the bank staff and Mr. Taro is the customer. When they are practice the conversation, there is misunderstanding between them. Mr. Brown says "Good morning sir." but Mr. Taro says "It is not good morning time, it is good night time." While staring at the window pointed the night sky.

\section{Data Interpretation:}

Mr. Brown and Mr. Taro are in conversation practice. Mr. Brown pretends as the bank staff says "Good morning sir." as the greeting to the customer like a staff of a bank always do, but Mr. Taro does not understand that Mr. Brown is only pretending and says "It is not good morning time, it is good night time." While pointed to the night sky out of the window signify is a night. It means that Mr. Taro does not agree with Mr. Brown and the violation of agreement maxim is happened in the conversation.

\subsubsection{Violation of Sympathy Maxim}

Leech as stated in [12] defines sympathy maxim is expressed by assertive and expressive utterances. This maxim requires every communicator to maximize sympathy and minimize antipathy to the listener. However, in Mind Your Language comedy series the actors ignored sympathy maxim in order to create humorous utterances. The violation of agreement maxim happened because the actors of Mind Your Language comedy series minimize sympathy and maximize antipathy. The following is the violation of sympathy maxim in Mind Your Language comedy series.

\section{Scene 1.}

Mr. Brown: So why don't you just sit at the back for a moment, and I'll get your particulars later.

Mr. Kenyon: But, please, (interrupt by Mr. Brown)

Mr. Brown: Be a good chap! Don't argue, just sit down. (Episode 2/11.52')

\section{Situation:}

This conversation happened in a class. It involves Mr. Brown and Mr. Kenyon. When Mr. Kenyon enters the class, Mr. Brown instructs him to sit down. Actually Mr. Kenyon wants to introduce himself first, but Mr. Brown does not give him a chance.

\section{Data Interpretation:}

Mr. Kenyon is actually a school inspector. He is assigned to control the classes. When he enters Mr. Brown class, Mr. Brown directly instructs him to sit down without asks his name or occupation and suppose Mr. Kenyon as a student. Mr. Kenyon wants to introduce himself, but Mr. Brown does not give him a chance. There is a violation of sympathy maxim in this conversation because Mr. Brown does not pay attention to the interlocutor.

\subsection{Effects of politeness principles violations}

\subsubsection{Effect of tact maxim violation}

Based on the examples in 4.1.1 above, it was found out that the tact maxim violations brought several effects, such as trusted in dialogue Ah Yes Danielle (student), at the moment, she is in the tearoom with Italy, Spain and Greece trying to establish diplomatic relations. (Episode 1/14.53') and confusion in dialogue Fly, in a big iron bird, quite a change from riding on elephant, unless you came by Jumbo. (Mr. Brown laughing) English joke. (Episode 2/17.34')

\subsubsection{Effect of Generosity Maxim violation}

Based on the examples in 4.1.2 above, it was found out that the tact maxim violations brought several effects, such as happy in dialogue I've always encouraged my stuff to be forward thinking. (Episode 2/21.57')

\subsubsection{Effect of Approbation Maxim violation}

Based on the examples in 4.1.3 above, it was found out that the tact maxim violations brought several effects, such as disappointed in dialogue I think she's is lost it already. (Episode 3/20.53')

\subsubsection{Effect of Modesty Maxim violation}

Based on the examples in 4.1.4 above, it was found out that the tact maxim violations brought several effects, such as shocked in dialogue I am Sikh. (Episode 1/11.00')

\subsubsection{Effect of Agreement Maxim violation}

Based on the examples in 4.1.5 above, it was found out that the tact maxim violations brought several effects, such as angry in dialogue It is not good morning time, it is good night time. (Episode 5/9.06')

\subsubsection{Effect of Sympathy Maxim violation}

Based on the examples in 4.1.6 above, it was found out that the tact maxim violations brought several effects, such as 
confused in dialogue be a good chap! Don't argue, just sit down. (Episode 2/11.52')

\section{CONCLUSIONS AND RECOMMENDATIONS}

\subsection{Conclusions}

Politeness principles violation is divided into six maxims by Leech (1983) as stated in [17] such are; tact maxim, generosity maxim, approbation maxim, modesty maxim, agreement maxim, and sympathy maxim. This study aimed to find out the politeness principles violation as the source of humor in Mind Your Language comedy series. There were 42 utterances taken episode 1-5 in this comedy series which are considered as politeness principles violation. These violations consist of tact maxim, generosity maxim, approbation maxim, modesty maxim, agreement maxim, and sympathy maxim.

The politeness principles violation in Mind Your Language comedy series happened as a method to create humorous situation. The actors of Mind Your Language comedy series tend to use violation of politeness principles in order to make a humor. [5] said that conflict and violation of pragmatic rules such as cooperative and politeness principles is a based to create humorous utterances. Conversation will be considered successful if the listener catches the message conveyed by the speaker but when the message is not delivered in appropriate way, it make the listener feels humiliated or offended by the speaker but sometimes turns out it makes a humor [7]. In Mind Your Language comedy series, the embarrassing and offending utterances are created to make a funny effect in order to make the viewers of the movie feels entertained.

In addition, politeness principles violation in Mind Your Language comedy series has several effects in the conversation. There are 14 effects from 42 violation such as; confuse, curious, angry, annoyed, happy, trust, shy, enthusiastic, strange, shock, disappointed, laugh, bored, and panic. All the effects are experienced by the interlocutor in the conversation.

\subsection{Recommendations}

Based on the results of this study concern in politeness principles violation of Mind Your Language comedy series, the researchers provided several recommendations for the students, the teachers, and other researchers. In relation to the students, it is expected that students should be inspired by the learning process situation in Mind Your Language comedy series. The researchers hopes that students will consider using politeness principles violation as a humor in classroom activity. The researchers hopes that the students will be inspired to use humor in classroom to create enjoyable atmosphere in the learning process. In addition, this study is beneficial for the teachers in that they should know that if there are some students in class who say an utterance that consider as violation of politeness principles, the purpose is perhaps to create a humorous situation and the researchers suggest for the teacher a consideration to use humor in classroom activities to support the successful of learning process. Finally, this study is also useful for the other researchers who want to conduct a similar study in wider area. Thus, the result will be more in-depth and generated.

\section{REFERENCES}

[1] K. Matwick and K. Matwick, "Self-deprecatory humor on TV cooking shows," Language \& Communication, vol. 56, pp. 3341, 2017.

[2] M. Dynel, "Humorous phenomena in dramatic discourse," The European Journal of Humour Research, vol. 1, pp. 22-60, 2013.

[3] Z. Ma and M. Jiang, "Interpretation of verbal humor in the sitcom The Big Bang Theory from the perspective of adaptation-relevance theory," Theory and Practice in Language Studies, vol. 3, p. 2220, 2013.

[4] O. H. Lynch, "Humorous communication: Finding a place for humor in communication research," Communication theory, vol. 12, pp. 423-445, 2002.

[5] Q. Mubarokah, D. Djatmika, and S. Sumarlam, "Cucuk Lampah: Cooperative Principles Violations to Create Laughter at Wedding Ceremony in Magetan," Lingua Cultura, vol. 13, pp. 231-237, 2019.

[6] E. Purwanti, "Wacana humor dalam komedi Extravaganza:: Kajian Sosiopragmatik," Universitas Gadjah Mada, 2006.

[7] A. Rohmahwati and I. Yuliasri, "Violation of politeness maxims in the television series the big bang theory," English Education Journal, vol. 7, pp. 66-72, 2017.

[8] H. Haryanto, S. Weda, and N. Nashruddin, "Politeness principle and its implication in EFL classroom in Indonesia," XLinguage" european Scientific Language Journal", vol. 11, pp. 90-112, 2018.

[9] W. Jie and W. Feifei, "The application of politeness principle in the analysis of drama: Take Teahouse as an example," Cross-Cultural Communication, vol. 12, pp. 35-38, 2016.

[10] E. Pebriantika, "Conversational Implicature and Politeness Principles in Sumbawanese Daily Conversations," Jurnal Kependidikan: Jurnal Hasil Penelitian dan Kajian Kepustakaan di Bidang Pendidikan, Pengajaran dan Pembelajaran, vol. 3, 2017.

[11] K. Olaniyi, "Politeness principle and Ilorin greetings in Nigeria: A sociolinguistic study," International Journal of Society, Culture \& Language, vol. 5, pp. 58-67, 2017.

[12] A. Rosyidha, I. N. Afdiyani, A. D. Fatimah, and I. Nisa, "Rethinking Politeness Principle in Pragmatics Study," Journal of Pragmatics Research, vol. 1, pp. 23-29, 2019.

[13] P. Lulu, "Pragmatic Differences Between Cooperative Principle and Politeness Principle in Chinese and English Commentators' Utterances," International Journal of English Language and Linguistics Research, vol. 7, pp. 33-46, 2019.

[14] I. Miranda, "The Cooperative, Relevance, and Politness Principles in Jokes: Interpretation and complementariness," ed: Universidad de La Rioja, 2013.

[15] L. Liu, "Application of Cooperative Principle and Politeness Principle in class question-answer process," Theory and Practice in Language Studies, vol. 7, p. 563, 2017.

[16] J. W. Creswell and J. D. Creswell, Research design: Qualitative, quantitative, and mixed methods approaches: Sage publications, 2017.

[17] N. L. P. Y. Kusuma, I. N. Sudiana, and I. W. Rasna, "Penerapan prinsip kerjasama dan prinsip kesopanan dalam tuturan Ir. Joko Widodo pada video debat Pilpres 2019," Jurnal Pendidikan dan Pembelajaran Bahasa Indonesia, vol. 9, pp. 36-46, 2020. 